\title{
Growth Performance of Melia dubia in Sole and Melia dubia- Sorghum Sudan Grass Silvi-Pasture Systems: Sorghum Sudan Grass Intercropping Implications
}

\author{
D. R. Prajapati ${ }^{*}$, N. S. Thakur ${ }^{1}$, R. P. Gunaga1, V. R. Patel ${ }^{2}$, \\ R. J. Mevada ${ }^{1}$ and D. C. Bhuva ${ }^{1}$ \\ ${ }^{1}$ College of Forestry, Navsari Agricultural University, Navsari, Gujarat-394340, India \\ ${ }^{2}$ Vanbandhu College of Veterinary Sciences and Animal Husbandry, Navsari Agricultural \\ University, Navsari, Gujarat-394340, India \\ *Corresponding author
}

\begin{tabular}{l} 
K e y w o r d s \\
Melia dubia, \\
$\begin{array}{l}\text { Sorghum sudan } \\
\text { grass, Silvi-pasture, } \\
\text { Volume, Biomass }\end{array}$ \\
\hline Article Info \\
\hline $\begin{array}{l}\text { Accepted: } \\
\text { 07 March } 2020 \\
\text { Available Online: } \\
10 \text { April } 2020\end{array}$
\end{tabular}

\section{A B S T R A C T}

M. dubia growth and yield performance was evaluated using Randomized Block Design with 10 treatments. There was significant variation in tree height $(\mathrm{m})$, girth at breast height $(\mathrm{GBH})(\mathrm{cm})$, and standing volume $\left(\mathrm{m}^{3} /\right.$ tree or $\left./ \mathrm{ha}\right)$ and biomass $(\mathrm{kg} /$ tree or $\mathrm{t} / \mathrm{ha})$, at SSG intercropping (July, 2019) and final SSG forage harvest (November, 2019), among the silvi-pasture $\left(\mathrm{T}_{1}\right.$ to $\left.\mathrm{T}_{5}\right)$ and sole plantation $\left(\mathrm{T}_{6}\right.$ to $\left.\mathrm{T}_{10}\right)$ systems. The increment put up in growth and yield attributes over the SSG intercropping period also differed significantly. At the SSG planting period, the height $(8.05 \mathrm{~m})$ and $\mathrm{GBH}(33.85 \mathrm{~cm})$ was higher under $M$. dubia $(3 \times 3 \mathrm{~m})$-SSG system and sole $M$. dubia plantation at $4 \times 4 \mathrm{~m}$, respectively. However, M. dubia $(4 \times 2 \mathrm{~m})-\mathrm{SSG}$ system was higher in height $(9.99 \mathrm{~m}), \mathrm{GBH}(44.18 \mathrm{~cm})$ and increment in both i.e. height $(2.94 \mathrm{~m})$ and $\mathrm{GBH}(15.53 \mathrm{~cm})$ at the SSG final harvest. At the time of SSG planting, volume $\left(0.070 \mathrm{~m}^{3} /\right.$ tree $)$ and biomass $(34.73 \mathrm{~kg} /$ tree $)$ per tree were higher in trees from sole $M$. dubia plantation at $4 \times 4 \mathrm{~m}$ spacing, however, at the final SSG harvest, M. dubia $(4 \times 2 \mathrm{~m})$-SSG system was higher in volume $\left(0.156 \mathrm{~m}^{3} /\right.$ tree $)$, biomass $(77.14 \mathrm{~kg} /$ tree $)$ and increment in per tree volume $\left(0.109 \mathrm{~m}^{3} /\right.$ tree $)$ and per tree biomass $(53.72 \mathrm{~kg} / \mathrm{tree})$. The volume and biomass per hectare, at the time of SSG planting, was higher $\left(84.69 \mathrm{~m}^{3} / \mathrm{ha}\right.$ and $41.92 \mathrm{t} / \mathrm{ha}$, respectively) in sole $M$. dubia $(3 \times 2 \mathrm{~m})$ plantation, whereas, same geometry in the M. dubia-SSG based silvi-pasture system produced highest volume $\left(199.94 \mathrm{~m}^{3} / \mathrm{ha}\right)$ and biomass $(98.97 \mathrm{~kg} / \mathrm{ha})$. However, increment in volume and biomass per hectare were higher $\left(128.83 \mathrm{~m}^{3} / \mathrm{ha}\right.$ and $63.77 \mathrm{~kg} / \mathrm{ha}$, respectively). The results showed that intercropping of SSG under $M$. dubia plantation has beneficial effect on growth and yield attributes of $M$. dubia.

\section{Introduction}

Melia dubia, belonging to the family meliaceae, found common in moist deciduous forests of the Indian states of Kerala, Karnataka (Nuthan et al., 2009), Tamilnadu
(Parthiban et al., 2009) Gujarat (Chauhan et $a l ., 2018)$ etc. is one of the fast growing tree species (Parthiban et al., 2009; 2018; Thakur et al., 2019b). It has emerged as an alternative raw material tree crop for the pulp and paper industries due to its increased pulp recovery 
and special strength of paper (Parthiban et al., 2009). Besides an important industrial tree species, it has also ecological importance like soil enrichment, afforestation and phytoremediation (Nuthan et al., 2009); medicinal uses (Malarvannan et al., 2009; Yasodha et al., 2011), fruit pulp as livestock feed (Sukhadiya et al., 2019 \&2020). It is also proven to be the most compatible agroforestry tree species amenable with different understorey crops (Jilariya et al., 2017; Thakur et al., 2018; Thakur et al., 2019a; Mohanty et al., 2019) with transient or no allelopathic effect on intercrops (Kumar et al., 2017; Thakur et al., 2017a\&b; Parmar et al., 2019).

It has been reported that $M$. dubia based agroforestry systems are profitable than that of monocropping systems (Anusha, 2012, Jilariya et al., 2019; Mohanty et al., 2017). Even though it is being widely adopted as tree component in different types of agroforestry systems, the effect on $M$. dubia growth due to intercropping of understory crop is still need to be explored. Therefore, taking this into consideration, present study was carried out to estimate the growth and productivity of different spatial geometries of $M$ dubiasorghum sudan grass (SSG) based silvipasture systems and sole plantation systems as affected by intercropping of SSG.

\section{Materials and Methods}

The current study was carried out at the College of Forestry, ACHF, NAU, Navsari, Gujarat, during 2019-20. The experiment was conducted following randomized block design with 10 treatmentsviz. $\mathrm{T}_{1}[M$. dubia $(2 \times 2 \mathrm{~m})$ $+\mathrm{SSG}], \mathrm{T}_{2}[$ M. dubia $(3 \times 3 \mathrm{~m})+\mathrm{SSG}], \mathrm{T}_{3}$ [M. dubia $(3 \times 2 \mathrm{~m})+\mathrm{SSG}], \mathrm{T}_{4}[$ M. dubia $(4$ $\times 4 \mathrm{~m})+\mathrm{SSG}], \mathrm{T}_{5}[$ M. dubia $(4 \times 2 \mathrm{~m})+$ SSG] and $\mathrm{T}_{6}$ to $\mathrm{T}_{10}$ sole M. dubia at $2 \times 2,3 \times$ $3,3 \times 2,4 \times 4$ and $4 \times 2 \mathrm{~m}$, respectively, with 4 replications. The $M$. dubia trees were of 5 years of age. Height and girth at breast height (GBH) were measured both at sowing (July, 2019) and final harvest of SSG forage (October, 2019). Volume and biomass were extrapolated to per hectare basis considering $5 \%$ mortality in each spatial geometry. The standing tree volume was calculated using standard formulae [Volume $\left(\mathrm{m}^{3} /\right.$ tree $)=\mathrm{g}^{2} \times$ $\mathrm{h} / 4 \pi$ where, $\mathrm{g}=$ Girth at Breast Height $(\mathrm{cm}), \mathrm{h}$ $=$ height of tree $(\mathrm{m})]$ then the volume was multiplied with specific gravity of the wood to get total biomass of the tree.

The statistical analysis of the data was done using randomized block design and ANOVA was prepared following Sheoran et al., (1998).

\section{Results and Discussion}

The data presented in the table 1, 2 and 3 revealed that, growth i.e. height $(\mathrm{m})$ and $\mathrm{GBH}$ $(\mathrm{cm})$ and yield attributes i.e. volume $\left(\mathrm{m}^{3} /\right.$ tree or $\left.\mathrm{m}^{3} / \mathrm{ha}\right)$ and biomass $(\mathrm{kg} /$ tree or $\mathrm{t} / \mathrm{ha})$ expressed significant differences $(\mathrm{P}<0.05)$ among $M$. dubia-SSG silvi-pasture systems ( $\mathrm{T}_{1}$ to $\mathrm{T}_{5}$ ) formed due to spatial configurations viz., $2 \times 2,3 \times 2,3 \times 3,4 \times 2$ and $4 \times 4 \mathrm{~m}$ of M. dubia and subsequent intercropping of SSG, and $M$. dubia sole plantations ( $\mathrm{T}_{6}$ to $\mathrm{T}_{10}$ ) at same spatial magnitude. The increment puton by trees in silvi-pasture systems and sole plantations, during one year of growth period also varied significantly.

\section{Height growth and increment (m)}

The results on height growth (Table 1) revealed that, initially (at sowing of SSG) tallest trees $(8.05 \mathrm{~m})$ were under $M$. dubia (3 x $3 \mathrm{~m}$ )-SSG system, which was at par with those of M. dubia (3 x 2 m)-SSG, M. dubia (4 x $4 \mathrm{~m}$ )-SSG systems, sole $M$. dubia planted at $3 \times 2 \mathrm{~m}, 3 \times 3 \mathrm{~m}$ and $4 \times 4 \mathrm{~m}$. Minimum tree height $(5.30 \mathrm{~m})$ was of trees under sole $M$. dubia $(2 \times 2 \mathrm{~m})$ plantation i.e. treatment $\mathrm{T}_{6}$. 
However, at the end of intercropping period, significantly maximum height $(9.99 \mathrm{~m})$ and increment $(2.94 \mathrm{~m})$ put up by trees was in $M$. dubia (4 x $2 \mathrm{~m})-\mathrm{SSG}\left(\mathrm{T}_{4}\right)$ system. Minimum tree height $(6.88 \mathrm{~m})$ and increment $(1.00 \mathrm{~m})$ was recorded under sole plantation of $M$. dubia at $2 \times 2 \mathrm{~m}$ and $4 \times 2 \mathrm{~m}$, respectively.

\section{Girth at breast height (GBH) and} increment $(\mathbf{c m})$

The data presented in the table 1 revealed that significantly maximum GBH $(33.85 \mathrm{~cm})$ of M. dubia at SSG planting was of trees under sole plantation having 4 x $4 \begin{array}{lll} & \mathrm{m} & \text { spatial }\end{array}$ geometry and the trees from sole plantation at $2 \times 2 \mathrm{~m}$ were recorded with lowest GBH of $20.10 \mathrm{~cm}$. At the end of SSG intercropping, GBH of trees under M. dubia (4 x 2 m)-SSG system was maximum $(44.18 \mathrm{~cm})$ and the minimum $(29.28 \mathrm{~cm})$ was of trees in $M$. dubia $(2 \times 2 \mathrm{~m})$ sole plantation.

Further, GBH increment (difference in GBH at final SSG harvest and at sowing of SSG) was put up maximum $(15.53 \mathrm{~cm})$ by the trees under M. dubia (4 x $2 \mathrm{~m})$-SSG ( $\left.\mathrm{T}_{4}\right)$ silvipasture system and minimum GBH increment $(8.20 \mathrm{~cm})$ was put up by the trees under $M$. dubia $(4 \times 2 \mathrm{~m})$ sole plantation.

\section{Volume and increment $\left(\mathrm{m}^{3} /\right.$ tree $)$}

The results indicated that significantly maximum per tree volume (at SSG sowing) to the tune of $0.070 \mathrm{~m}^{3} /$ tree was of trees under sole $M$. dubia planted at $4 \times 4 \mathrm{~m}$ and minimum $\left(0.017 \mathrm{~m}^{3} /\right.$ tree $)$ was under $M$. dubia $(2 \times 2 \mathrm{~m})$ sole plantation (Table 2). However, at SSG final harvest, significantly maximum volume $\left(0.156 \mathrm{~m}^{3} /\right.$ tree $)$ was of trees in $M$. dubia (4 $\mathrm{x} 2 \mathrm{~m})-\mathrm{SSG}$ system and the minimum per tree volume $\left(0.047 \mathrm{~m}^{3} /\right.$ tree $)$ was recorded under sole plantation of $M$. dubia planted at $2 \times 2 \mathrm{~m}$ geometry. The increment in volume per tree was put up maximum $(0.109$ $\mathrm{m}^{3} /$ tree) by the trees under M. dubia $(4 \times 2$ $\mathrm{m})$-SSG $\left(\mathrm{T}_{4}\right)$ system and the lowest volume increment i.e. $0.030 \mathrm{~m}^{3} /$ tree was put up by the trees from $M$. dubia $2 \times 2 \mathrm{~m}\left(\mathrm{~T}_{6}\right)$ sole plantation (Table 2).

\section{Biomass and increment ( $\mathrm{kg} /$ tree)}

The data in the table 2 evinced that per tree standing biomass was significantly maximum (34.73 kg/tree) under sole $M$. dubia spaced at 4 x $4 \mathrm{~m}$, whereas, minimum $(8.51 \mathrm{~kg} /$ tree $)$ was recorded under $M$. dubia sole plantation with $2 \times 2 \mathrm{~m}$ spacing. However, at the final SSG forage harvest, biomass and its increment were maximum (77.14 and 53.72 $\mathrm{kg} / \mathrm{tree}$, respectively) of trees in M. dubia (4 x $2 \mathrm{~m})-\mathrm{SSG}$ system. The minimum per tree biomass $(23.31 \mathrm{~kg})$ and its increment (14.81 $\mathrm{kg} /$ tree) were recorded for the trees under sole plantation of $M$. dubia at $2 \times 2 \mathrm{~m}$ spacing.

\section{Volume and increment $\left(\mathrm{m}^{3} / \mathrm{ha}\right)$}

The data illustrated in the table 3 indicated that, at SSG intercropping, the maximum wood volume production $\left(84.69 \mathrm{~m}^{3} / \mathrm{ha}\right)$ was under sole $M$. dubia plantation spaced at $3 \times 2$ $\mathrm{m}$ and minimum $\left(37.27 \mathrm{~m}^{3} / \mathrm{ha}\right)$ was recorded under $M$. dubia sole plantation at $2 \times 2 \mathrm{~m}$ spacing. However, at final SSG forage harvest, highest wood volume $\left(199.94 \mathrm{~m}^{3} / \mathrm{ha}\right)$ from $M$. dubia (3 x 2 m)-SSG system, whereas, lowest $\left(76.12 \mathrm{~m}^{3} / \mathrm{ha}\right)$ was recorded in M. dubia (4 x $4 \mathrm{~m}$ )-SSG system. Further, the increment in wood volume was put-up maximum $\left(128.83 \mathrm{~m}^{3} / \mathrm{ha}\right)$ by trees under $M$. dubia (4 x $2 \mathrm{~m}$ )-SSG silvi-pasture system and minimum $\left(38.85 \mathrm{~m}^{3} / \mathrm{ha}\right)$ was of those under M. dubia (4 x 4 m)-SSG silvi-pasture system (Table 3).

\section{Biomass and increment (t/ha)}

The data pertaining to biomass at SSG planting (Table 3) revealed that $M$. dubia sole 
plantation with spatial configuration $3 \times 2 \mathrm{~m}$ recorded with highest biomass (41.92 t/ha) and lowest (18.45 t/ha) was under M. dubia (4 x $4 \mathrm{~m}$ )-SSG system. However, at SSG final harvest, maximum wood biomass to the tune of $98.97 \mathrm{t} /$ ha was gained by the trees under $M$. dubia (3 x $2 \mathrm{~m}$ )-SSG silvi-pasture system and minimum $M$. dubia wood biomass (37.68 t/ha) was recorded under $M$. dubia at (4 x 4 m)-SSG silvi-pasture system.

Further, maximum wood biomass increment (63.77 t/ha) was acquired under M. dubia (4 x $2 \mathrm{~m}$ )-SSG system, whereas, M. dubia (4 x 4 $\mathrm{m})$-SSG $\left(\mathrm{T}_{5}\right)$ system exhibited minimum biomass increment i.e. $19.23 \mathrm{t} / \mathrm{ha}$ (Table 3). Overall, the present investigation pointed out that there were significant differences observed in growth and yield attributes of $M$. dubia either in silvi-pasture or sole plantation systems. Both, the growth and yield parameters including increments in them were higher under silvi-pasture system compared to sole plantation systems, which confirm the beneficial effect of conflating $M$. dubia with SSG as intercrop.

Similar findings were put forth by Khan and Chaudhary (2007) in Populus deltoids, Thakur et al., (2019b) and Jilariya et al., (2017) in M. dubia. The overall divergence in the volume and biomass were due to the tree numbers in lesser spacings which directly affected total yield in both terms. This reveals that growth is the cumulative result of age, spacing and site quality (Nissen et al., 2001). In the wider spacings, more availability of light, water and nutrients resulting in increase in crown size, leaf area and synthesis of carbohydrates and hormonal growth regulators may have improved the height and GBH growth (Baldwin et al., 2000; Nissen et al., 2001; Zang et al., 2013; Thakur et al., 2019b).

Table.1 Comparative growth attributes of $M$. dubia under $M$. dubia-SSG silvi-pasture systems and sole M. dubia plantations

\begin{tabular}{|c|c|c|c|c|c|c|}
\hline \multirow{2}{*}{$\begin{array}{l}\text { Land use } \\
\text { systems }\end{array}$} & \multicolumn{2}{|c|}{ Height (m) } & \multicolumn{2}{|c|}{ GBH $(\mathbf{c m})$} & \multicolumn{2}{|c|}{ Increment } \\
\hline & $\begin{array}{l}\text { At SSG } \\
\text { planting }\end{array}$ & $\begin{array}{c}\text { At SSG } \\
\text { final } \\
\text { harvest }\end{array}$ & $\begin{array}{l}\text { At SSG } \\
\text { planting }\end{array}$ & $\begin{array}{c}\text { At SSG } \\
\text { final } \\
\text { harvest }\end{array}$ & $\begin{array}{l}\text { Height } \\
\text { (m/tree) }\end{array}$ & $\begin{array}{c}\text { GBH } \\
(\mathrm{cm} / \text { tree })\end{array}$ \\
\hline $\mathbf{T}_{1}$ & 5.73 & 7.30 & 21.75 & 31.18 & 1.58 & 9.43 \\
\hline $\mathbf{T}_{2}$ & 7.55 & 9.23 & 29.13 & 41.03 & 1.68 & 11.90 \\
\hline $\mathbf{T}_{\mathbf{3}}$ & 8.05 & 9.90 & 28.10 & 39.13 & 1.85 & 11.03 \\
\hline $\mathbf{T}_{4}$ & 7.05 & 9.99 & 28.65 & 44.18 & 2.94 & 15.53 \\
\hline $\mathbf{T}_{5}$ & 7.33 & 8.73 & 32.80 & 43.00 & 1.40 & 10.20 \\
\hline $\mathbf{T}_{6}$ & 5.30 & 6.88 & 20.10 & 29.28 & 1.58 & 9.18 \\
\hline $\mathbf{T}_{7}$ & 7.48 & 8.78 & 30.00 & 39.33 & 1.30 & 9.33 \\
\hline $\mathbf{T}_{8}$ & 7.78 & 9.60 & 31.88 & 43.58 & 1.83 & 11.70 \\
\hline $\mathbf{T}_{9}$ & 6.90 & 7.90 & 31.05 & 39.25 & 1.00 & 8.20 \\
\hline $\mathbf{T}_{10}$ & 7.68 & 9.03 & 33.85 & 44.08 & 1.35 & 10.23 \\
\hline $\operatorname{SEm}( \pm)$ & 0.28 & 0.27 & 1.71 & 1.84 & 0.24 & 1.34 \\
\hline $\mathrm{CD}_{(0.05)}$ & 0.82 & 0.80 & 4.98 & 5.37 & 0.69 & 3.92 \\
\hline CV (\%) & 7.96 & 6.28 & 11.89 & 9.34 & 28.49 & 25.18 \\
\hline
\end{tabular}

Note: $\mathrm{T}_{1}=$ M. dubia $(2 \times 2 \mathrm{~m})-\mathrm{SSG}, \mathrm{T}_{2}=$ M. dubia $(3 \times 2 \mathrm{~m})-\mathrm{SSG}, \mathrm{T}_{3}=$ M. dubia $(3 \times 3 \mathrm{~m})-\mathrm{SSG}, \mathrm{T}_{4}=M$. dubia $(4 \times$ $2 \mathrm{~m})-\mathrm{SSG}, \mathrm{T}_{5}=$ M. dubia $(4 \times 4 \mathrm{~m})-\mathrm{SSG}, \mathrm{T}_{6}=$ M. dubia $(2 \mathrm{mX} 2 \mathrm{~m}), \mathrm{T}_{7}=M$. dubia $(3 \times 2 \mathrm{~m}), \mathrm{T}_{8}=$ M. dubia $(3$ х $3 \mathrm{~m}), \mathrm{T}_{9}=M$.dubia $(4 \times 2 \mathrm{~m}), \mathrm{T}_{10}=M$. dubia $(4 \times 4 \mathrm{~m})$ 
Table.2 Volume $\left(\mathrm{m}^{3} /\right.$ tree) and biomass (kg/tree) of $M$. dubia under M. dubia-SSG silvi-pasture systems and sole $M$. dubia plantations

\begin{tabular}{|c|c|c|c|c|c|c|}
\hline \multirow{2}{*}{$\begin{array}{l}\text { Land use } \\
\text { systems }\end{array}$} & \multicolumn{2}{|c|}{ Volume $\left(\mathrm{m}^{3} /\right.$ tree $)$} & \multicolumn{2}{|c|}{ Biomass (kg/tree) } & \multicolumn{2}{|c|}{ Increment } \\
\hline & $\begin{array}{c}\text { At SSG } \\
\text { planting }\end{array}$ & $\begin{array}{c}\text { At SSG } \\
\text { final harvest }\end{array}$ & $\begin{array}{c}\text { At SSG } \\
\text { planting }\end{array}$ & $\begin{array}{c}\text { At SSG } \\
\text { final harvest }\end{array}$ & $\begin{array}{l}\text { Volume } \\
\left(\mathrm{m}^{3} / \text { tree }\right)\end{array}$ & $\begin{array}{l}\text { Biomass } \\
\text { (kg/tree) }\end{array}$ \\
\hline $\mathbf{T}_{1}$ & 0.022 & 0.057 & 10.79 & 28.36 & 0.036 & 17.57 \\
\hline $\mathbf{T}_{2}$ & 0.052 & 0.126 & 25.58 & 62.52 & 0.075 & 36.94 \\
\hline $\mathbf{T}_{3}$ & 0.053 & 0.123 & 26.44 & 60.82 & 0.069 & 34.38 \\
\hline $\mathbf{T}_{4}$ & 0.047 & 0.156 & 23.42 & 77.14 & 0.109 & 53.72 \\
\hline $\mathbf{T}_{5}$ & 0.063 & 0.128 & 31.11 & 63.54 & 0.066 & 32.43 \\
\hline $\mathbf{T}_{6}$ & 0.017 & 0.047 & 8.51 & 23.31 & 0.030 & 14.81 \\
\hline $\mathbf{T}_{7}$ & 0.054 & 0.108 & 26.48 & 53.38 & 0.054 & 26.90 \\
\hline $\mathbf{T}_{8}$ & 0.065 & 0.147 & 32.21 & 72.98 & 0.082 & 40.77 \\
\hline $\mathbf{T}_{9}$ & 0.053 & 0.097 & 26.31 & 47.90 & 0.044 & 21.59 \\
\hline$T_{10}$ & 0.070 & 0.140 & 34.73 & 69.26 & 0.070 & 34.52 \\
\hline $\operatorname{SEm}( \pm)$ & 0.008 & 0.013 & 3.75 & 6.21 & 0.010 & 4.87 \\
\hline $\mathrm{CD}_{(0.05)}$ & 0.022 & 0.037 & 10.94 & 18.13 & 0.029 & 14.22 \\
\hline CV (\%) & 30.527 & 22.228 & 30.55 & 22.23 & 31.079 & 31.08 \\
\hline
\end{tabular}

Note: $\mathrm{T}_{1}=$ M. dubia $(2 \times 2 \mathrm{~m})-\mathrm{SSG}, \mathrm{T}_{2}=$ M. dubia $(3 \times 2 \mathrm{~m})-\mathrm{SSG}, \mathrm{T}_{3}=$ M. dubia $(3 \times 3 \mathrm{~m})-\mathrm{SSG}, \mathrm{T}_{4}=$ M. dubia $(4 \times$ $2 \mathrm{~m})$-SSG, $\mathrm{T}_{5}=$ M. dubia $(4 \times 4 \mathrm{~m})-\mathrm{SSG}, \mathrm{T}_{6}=M$. dubia $(2 \mathrm{mX} 2 \mathrm{~m}), \mathrm{T}_{7}=M$. dubia $(3 \times 2 \mathrm{~m}), \mathrm{T}_{8}=M$. dubia $(3$ х $3 \mathrm{~m}), \mathrm{T}_{9}=M$.dubia $(4 \times 2 \mathrm{~m}), \mathrm{T}_{10}=M$. dubia $(4 \times 4 \mathrm{~m})$

Table.3 Volume $\left(\mathrm{m}^{3} / \mathrm{ha}\right)$ and biomass (t/ha) of $M$. dubia under $M$. dubia-SSG silvi-pasture systems

\begin{tabular}{|c|c|c|c|c|c|c|}
\hline \multirow{2}{*}{$\begin{array}{l}\text { Land use } \\
\text { systems }\end{array}$} & \multicolumn{2}{|c|}{ Volume $\left(\mathrm{m}^{3} / \mathrm{ha}\right)$} & \multicolumn{2}{|c|}{ Biomass (t/ha) } & \multicolumn{2}{|c|}{ Increment } \\
\hline & $\begin{array}{c}\text { At SSG } \\
\text { planting }\end{array}$ & $\begin{array}{c}\text { At SSG } \\
\text { final } \\
\text { harvest }\end{array}$ & $\begin{array}{c}\text { At SSG } \\
\text { planting }\end{array}$ & $\begin{array}{c}\text { At SSG } \\
\text { final } \\
\text { harvest }\end{array}$ & $\begin{array}{l}\text { Volume } \\
\left(\mathrm{m}^{3} / \mathrm{ha}\right)\end{array}$ & $\begin{array}{c}\text { Biomass } \\
\text { (t/ha) }\end{array}$ \\
\hline $\mathbf{T}_{1}$ & 51.78 & 136.06 & 25.63 & 67.35 & 84.28 & 41.72 \\
\hline $\mathbf{T}_{2}$ & 81.80 & 199.94 & 40.49 & 98.97 & 118.14 & 58.48 \\
\hline $\mathbf{T}_{3}$ & 56.35 & 129.62 & 27.90 & 64.16 & 73.27 & 36.26 \\
\hline $\mathbf{T}_{4}$ & 56.16 & 184.99 & 27.80 & 91.57 & 128.83 & 63.77 \\
\hline $\mathbf{T}_{5}$ & 37.27 & 76.12 & 18.45 & 37.68 & 38.85 & 19.23 \\
\hline $\mathbf{T}_{6}$ & 40.81 & 111.85 & 20.20 & 55.36 & 71.04 & 35.17 \\
\hline $\mathbf{T}_{7}$ & 84.69 & 170.71 & 41.92 & 84.50 & 86.02 & 42.58 \\
\hline $\mathbf{T}_{8}$ & 68.65 & 155.54 & 33.98 & 76.99 & 86.89 & 43.02 \\
\hline $\mathbf{T}_{9}$ & 63.09 & 114.87 & 31.23 & 56.86 & 51.78 & 25.63 \\
\hline $\mathbf{T}_{10}$ & 41.61 & 82.96 & 20.60 & 41.07 & 41.36 & 20.47 \\
\hline $\operatorname{SEm}( \pm)$ & 8.75 & 16.53 & 4.33 & 8.18 & 13.45 & 6.66 \\
\hline $\mathrm{CD}_{(0.05)}$ & 25.52 & 48.22 & 12.63 & 23.87 & 39.23 & 19.42 \\
\hline CV (\%) & 30.05 & 24.26 & 30.05 & 24.26 & 34.46 & 34.46 \\
\hline
\end{tabular}

Note: $\mathrm{T}_{1}=M$. dubia $(2 \times 2 \mathrm{~m})-\mathrm{SSG}, \mathrm{T}_{2}=M$. dubia $(3 \times 2 \mathrm{~m})-\mathrm{SSG}, \mathrm{T}_{3}=M$. dubia $(3 \times 3 \mathrm{~m})-\mathrm{SSG}, \mathrm{T}_{4}=M$. dubia $(4 \times$ $2 \mathrm{~m})-\mathrm{SSG}, \mathrm{T}_{5}=$ M. dubia $(4 \times 4 \mathrm{~m})-\mathrm{SSG}, \mathrm{T}_{6}=M$. dubia $(2 \mathrm{~m} \times 2 \mathrm{~m}), \mathrm{T}_{7}=M$. dubia $(3 \times 2 \mathrm{~m}), \mathrm{T}_{8}=M$. dubia $(3 \times 3$ $\mathrm{m}), \mathrm{T}_{9}=$ M. dubia $(4 \times 2 \mathrm{~m}), \mathrm{T}_{10}=$ M.dubia $(4 \times 4 \mathrm{~m})$ 
The growth and yield parameters of $M$. dubia planted at various spatial configurations, either in silvi-pasture systems or sole plantations, differed significantly due to intercropping of SSG. The findings suggested that maximum wood biomass, which is the ultimate salable product from the tree, can be obtained from the M. dubia planted at $3 \times 2 \mathrm{~m}$ and $4 \times 2$ spatial arrangements in silvi-pasture systems.

The maximum increment in wood biomass was also higher in the above mentioned two spatial configurations under silvi-pasture. Therefore, it can be substantiated from this study that silvi-pasture has positive effect on the M. dubia growth and yield performance and are considered best suited spatial arrangements for getting higher wood biomass.

\section{References}

Anusha 2012. Performance of finger millet and carbon sequestration in agroforestry system, M.Sc. Thesis, University of Agricultural Sciences, Bengaluru, 142p.

Baldwin, V. C. J. Peterson, K. D. Clark, A., III Ferguson, R. B. Strub, M. R. Bower, D. R. 2000. The effects of spacing and thinning on stand and tree characteristics of 38-year-old loblolly pine. Forest Ecology and Management, 137: 91-102.

Bhusara J. B., Dobriyal M. J., Thakur N. S., Gunaga R. P. and Tandel M. B. 2018. Performance of okra (Abelmoschus esculentus L. Moench) under different spatial arrangements of Meliacomposita based agroforestry system. International Journal of Current Microbiology and Applied Sciences, 7(5): 3533-3542.

Chauhan R. S., Jadeja D. B., Thakur N. S., Jha S. K., and Sankanur M. S. 2018. Selection of Candidate plus trees (CPTs) of Malabar Neem (Melia dubia Cav.) for enhancement of farm productivity in south Gujarat. International Journal of Current Microbiology and Applied Sciences 7(5): 3582-3592.
Jilariya D. J., Thakur N. S. and Gunaga R. P. 2017. Quantitative and qualitative attributes of Aloe vera Linn. grown under Melia composite Willd. and sole cropping systems. Indian Journal of Ecology, 44(5): 451- 455.

Jilariya, D J, Thakur N S Singh N and Gunaga R $\mathrm{P}$ 2019. Economics of cultivation of Melia dubia Cav.-Aloe vera L. silvimedicinal model. Indian Journal of Agroforestry 21(2): 35-40.

Khan G. S. and Chaudhry A. K. 2007. Effect of spacing and plant density on the growth of poplar (Populus deltoides) trees under agroforestry system. Pakistan Journal of Agricultural Sciences, 44(2): 321-327.

Kumar D., Thakur N. S. and Gunaga R. P. 2017. Effects of leaf aqueous extract and leaf litter of Melia composita Willd. on black gram (Vigna mungo (L.) Hepper). Allelopathy Journal 41(1): 127-140.

Malarvannan S., Giridharan R., Sekar S., Prabavathy V. R. and Sudha N. 2009. Ovicidal activity of crude extracts of few traditional plants against Helicoverpa armigera (Hubner) (Noctuidae: Lepidoptera). Journal of Biopesticides 2(1): 64-71.

Mohanty S, Thakur N. S., Gunaga R. P. and Gajbhiye N. 2019. Influence of Melia dubia Cav. spatial geometries on growth, herbage yield and essential oil constituents of Cymbopogon martinii (Roxb.) Wats. Journal of Essential Oil Bearing Plants, 22(3): 630-648.

Mohanty S, Thakur N. S., Gunaga R. P., Dobriyal M. J. and Desai B. S. (2017). Value addition in Cymbopogon spp. to enhance the financial flows from Cymbopogon spp.-Melia dubia Cav. based silvimedicinal and sole cropping systems. Indian Journal of Ecology 44(6): 812816.

Nissen T. M., Midmore D. J. and Keeler A. G. 2001. Biophysical and economic tradeoffs of intercropping timber with food crops in the Philippine uplands. Agricultural Systems, 67: 49-69.

Nuthan, D., Reddy K. M. C., Kumar, S. P. Vajranabhaiah S. N., Yogeesha T. D. 2009. Cultivation of Melia dubia on 
farmlands of Kanakapura taluka Ramanagara district of Karnataka-A success story Publication No 224, National Afforestation and Ecodevelopment Board (NAEB) Ministry of Environment and Forests Government of India University of Agricultural Sciences, GKVK Campus Bangalore India, RC, NAEB.

Parmar A. G., Thakur N. S. and Gunaga R. P. 2019. Melia dubia Cav. leaf litter allelochemicals have ephemeral allelopathic proclivity. Agroforestry Systems, 93(4): 1347-1360.

Parthiban K. T., Bharathi A. K., Seenivasan R., Kamala K. and Rao M. G. 2009. Integrating Melia dubia in agroforestry farms as an alternate pulpwood species. APA News 34: 3- 4.

Sheoran O. P., Tonk D. S., Kaushik L. S, Hasija R. C. and Pannu R. S. 1998. Statistical software package for agricultural research workers. In: Hooda D. S., Hasija R. C. (Eds) Recent Advances in information theory, Statistics \& Computer Applications by Department of Mathematics Statistics, CCS HAU, Hisar, India, Pp. 139-143.

Sukhadiya M. L., Thakur N. S., Gunaga R. P., Patel V. R., Bhuva D. C., Singh S. 2019. Melia dubia Cav. drupe pulp: a new alternate livestock feed resource. Range Management and Agroforestry, 40(2): 299-305.

Sukhadiya M. L., Thakur N. S., Patel V. R., Gunaga R. P., Kharadi V. B., Tyagi K. K. and Singh S. 2020. Provenance variations in proximate principles, mineral matter, total phenols and phytochemicals of Melia dubia drupes: an unexplored alternate livestock feed stock. Journal of Forestry https://doi.org/10.1007/s11676-019- 01080-y

Thakur N. S., Jilariya D. J., Gunaga R. P. and Singh S. 2018. Positive allelospoly of Melia dubia Cav. spatial geometry improve quantitative and qualitative attributes of Aloe vera L. Industrial Crops and Products, 119: 162-171.

Thakur, N. S., Kumar, D., Gunaga, R. P. and Singh, S. (2017a). Allelopathic propensity of the aqueous leaf extract and leaf litter of Melia dubia Cav. on pulse crops. Journal of Experimental Biology and Agricultural Sciences, 5(5): 644-655.

Thakur, N. S., Kumar, D. and Gunaga, R. P. (2017b).Transient allelopathic propensity of Melia composita Willd. leaf litter on chickpea (Cicer arietinum L.). Indian Journal of Ecology, 44(5): 443-450.

Thakur, N. S., Mohanty, S., Gunaga, R. P. and Gajbhiye, N. A. (2019a). Melia dubia Cav. spatial geometries influence the growth, yield and essential oil principles content of Cymbopogon flexuosus (Nees Ex Steud.) W. Watson. Agroforestry System.

Thakur, N. S., Mohanty, S., Hegde, H. T., Chauhan, R. S., Gunaga, R. P. and Bhuva, D. C. $(2019 b)$. Performance of Melia dubia under Cymbopogon spp. based agroforestry systems, Journal of Tree Sciences, 38(1): 28-34.

Yasodha D. M., Manimegalai Kumari, Binu S., Vijayakumar K. 2011. Larvicidal effect of Melia dubia seed extract against the malarial fever mosquito, Culex quinquefasciatus. Current Biotica, 5: 102106.

Zhang, J. Ritchie, M. W. Maguire, D. A. Oliver, W. W. 2013. Thinning ponderosa pine (Pinus ponderosa) stands reduces mortality while maintaining stand productivity. Canadian Journal of Forest Research, 43: 311-320.

\section{How to cite this article:}

Prajapati. D. R., N. S. Thakur, R. P. Gunaga V. R. Patel, R. J. Mevada and Bhuva, D. C. 2020. Growth Performance of Melia dubia in Sole and Melia dubia-Sorghum Sudan Grass SilviPasture Systems: Sorghum Sudan Grass Intercropping Implications. Int.J.Curr.Microbiol.App.Sci. 9(04): 726-732. doi: https://doi.org/10.20546/ijcmas.2020.904.086 